\title{
PENGARUH KONDISI FISIK LINGKUNGAN TERHADAP ANGKA KUMAN UDARA DAN KEBERADAAN BAKTERI STAPHYLOCOCCUS DI RUANG RAWAT INAP RUMAH SAKIT ISLAM FAISAL MAKASSAR
}

\section{The Influence Of Environmental Physical Conditions On The Numbers Of Air And The Existence Of Staphylococcus Bacteria In The Investigation \\ Of Faisal Islamic Hospital, Makassar}

\author{
Dian Anggraini, ${ }^{1}$ Nur Hamdani N. ${ }^{2}$ \\ ${ }^{1}$ Akademi Kesehatan Lingkungan Mandala Waluya Kendari \\ ${ }^{2}$ Fakultas Kesehatan Masyarakat, Universitas Pancasakti Makassar
}

Korespondensi : dian.anggraini37@yahoo.co.id

\begin{abstract}
ABSTRAK
Udara sangat mutlak diperlukan oleh setiap orang, namun adanya udara yang terkontaminasi oleh mikroba patogen dalam udara masuk ke saluran napas penjamu dalam bentuk droplet nuklei yang dikeluarkan oleh penderita saat batuk atau bersin, bicara atau bernapas melalui mulut atau hidung. Faktor lingkungan fisik udara tertentu dapat mempengaruhi angka kuman udara. Penelitian ini bertujuan untuk mengetahui pengaruh kondisi fisik lingkungan terhadap angka kuman udara dan mengidentifikasi keberadaan bakteri staphylococcus di ruang rawat inap Rumah Sakit Islam Faisal Makassar. Populasi pada penelitian ini adalah seluruh udara yang ada di ruang perawatan RSIF Makassar, yang diambil pada 30 titik/ruang perawatan. Desain yang digunakan adalah Cross Sectional, variabel independentnya lingkungan fisik dan variabel dependentnya angka kuman udara. Dengan menggunakan uji chi-square dengan tingkat kemaknaan $\alpha=0,05$ dan menggunakan uji regresi logistik untuk melihat variabel yang paling berpengaruh. Dari hasil identifikasi ditemukannya bakteri staphylococcus sp dan staphylococcus aureus pada ruang perawatan. Pada pengukuran masing- masing variabel menunjukkan bahwa sebagian besar variabel penelitian tidak memenuhi syarat sebagaimana yang ditetapkan oleh Keputusan Menteri Kesehatan RI No. 1204/MENKES/SK/X/2004. Hasil uji hubungan berdasarkan faktor lingkungan fisik terhadap angka kuman udara diperoleh nilai $p<0,05$ untuk suhu $(p=0,009)$, pencahayaan $(p=0,024)$, dan kelembaban $(p=0,034)$ yang berarti ada hubungan yang bermakna antara ketiga faktor lingkungan tersebut terhadap angka kuman
\end{abstract}

Kata Kunci: Bakteri Staphylococcus, Angka Kuman Udara, Lingkungan Fisik

\section{ABSTRACT}

Air is absolutely necessary for everyone, but the air contaminated by pathogenic microbes in the air enters the host's airways in the form of droplet nuclei which are released by the sufferer when coughing or sneezing, talking or breathing through the mouth or nose. Certain physical environmental factors in the air can affect the air germ count. This study aims to determine the effect of environmental physical conditions on air germ count and to identify the presence of staphylococcus bacteria in the inpatient room of Faisal Islamic Hospital Makassar. The population in this study was all the air in the RSIF Makassar treatment room, which was taken at 30 points / treatment rooms. The design used was cross sectional, the independent variable was the physical environment and the dependent variable was the air germ count. By using the chi-square test with a significance level of $\alpha=0.05$ and using a logistic regression test to see the most influential variables. From the identification results, staphylococcus sp and staphylococcus aureus were found in the treatment room. The measurement of each variable shows that most of the research variables do not meet the requirements as stipulated by the Decree of the Minister of Health of the Republic of Indonesia No. 1204 / MENKES / SK / X / 2004. The results of the relationship test based on physical environmental factors to the air germ count obtained $p$ value $<0.05$ for temperature $(p=0.009)$, lighting $(p=0.024)$, and humidity $(p=0.034)$ which means that there is a significant relationship between the three environmental factors. these against the germ count Keywords: Staphylococcus Bacteria, Air Germs Rate, Physical Environment. 


\section{PENDAHULUAN}

Perwujudan kualitas lingkungan yang sehat merupakan bagian pokok di bidang kesehatan. Udara sebagai komponen lingkungan yang penting dalam kehidupan perlu dipelihara dan ditingkatkan kualitasnya sehingga memberikan daya dukung bagi makhluk hidup untuk hidup secara optimal. Manusia memerlukan oksigen. Oksigen berada di udara, namun ketika manusia menghirup udara untuk menyerap oksigen, udara di sekeliling manusia berada sering kali tercemar atau tercampur bahan kimia, virus, bakteri maupun parasit yang merupakan agent penyakit. (Ahcmadi, 2013)

Pemerintah Indonesia telah mengatur persyaratan kualitas udara di rumah sakit dalam Keputusan Menteri Kesehatan RI No.1204/MENKES/SK/X/2004. Sebagai suatu institusi, rumah sakit memberikan pelayanan kesehatan dalam rangka mengobati dan menyembuhkan penderita, sehingga didapatkan kondisi yang sehat dan terbebas dari penyakit. Dalam kegiatannya terjadi interaksi antara pasien, pengunjung, petugas, peralatan medik, penunjang medik dan non medik, obat-obatan serta bahan lain. Kegiatan di rumah sakit memungkinkan untuk terjadinya pencemaran lingkungan, gangguan kesehatan dan atau dapat menjadi tempat penularan penyakit, yang disebut dengan infeksi nosokomial (Haryono, 2013).

Salah satu bakteri penyebab infeksi nosokomial yaitu bakteri Staphylococcus. Staphylococcus aureus merupakan flora normal kulit namun dapat bersifat patogen pada host yang rentan, bakteri ini mampu menyebabkan berbagai infeksi supuratif dengan angka keparahan yang bervariasi pada jaringan lunak, jaringan tulang, organ pernafasan, serta jaringan endovaskular yang menimbulkan manisvestasi berbagai penyakit seperti furunkel, impertigo, osteomyelitis, tonsilitis, bronhitis, pneumonia, endokarditis meningeosenfalitis, sampai sepsis. (Ray P. Dan Sing R, 2011 dalam Dewi dkk, 2016)

Penelitian yang dilakukan oleh Wikansari (2012) di kamar ruang rawat inap rumah sakit Kota Semarang, menunjukkan hasil bahwa ratarata kuman pada rawat inap kelas II dan III penyakit pasca bedah sebesar $281 \mathrm{CFU} / \mathrm{m} 3$ dan 717 CFU/m3, sedangkan rata-rata kuman pada ruang rawat inap kelas II dan kelas III penyakit dalam sebesar $1.095 \mathrm{CFU} / \mathrm{m} 3$ dan $1.522 \mathrm{CFU} / \mathrm{m} 3$. Sejumlah kamar memiliki angka kuman melebihi ambang batas total kuman di ruang rawat inap. Pada ruang rawat inap penyakit dalam ada beberapa ruang ditemukan Staphylococcus Aureus.

Ruang rawat inap rentan untuk terjadinya penularan penyakit. Berdasarkan hal tersebut mendorong peneliti untuk mengetahui bagaimana pengaruh lingkungan fisik terhadap angka kuman udara dan juga ingin mengidentifikasi bakteri staphylococcus di ruang rawat inap Rumah Sakit Islam Faisal Makassar.

\section{BAHAN DAN METODE}

Penelitian ini menggunakan metode observasional analitik dengan untuk melihat 
hubungan antara faktor lingkungan fisik terhadap angkka kuman udara dengan menggunakan rancangan cross sectionaL. Populasi pada penelitian ini adalah seluruh udara yang ada diruang rawat inap rumah sakit Islam Faisal Makassar yang diambil secara purposive sampling pada empat jenis ruang rawat inap (VIP, kelas I, kelas II, kelas III) dipilih sebagai subjek dan angka kuman udara dan 4 parameter lingkungan fisik (pencahayaan, suhu, kelembaban, dan kepadatan hunian) ditetapkan sebagai unit observasi. Pengambilan sampel dilakukan pada 30 titik/ruangan. Suhu dan kelembaban menggunakan alat termohygrometer alat mempunyai dua fungsi yang berbeda sehingga dapat digunakan bersamaan. Pencahayaan diukur dengan luxmeterkepadatan hunian dihitung sebagai luas ruangan (m2) per orang, sedangkan pengambilan sampel udara untuk pemeriksaan angka kuman udara dan identifikasi bakteri staphylococcus menggunakan alat Mikrobial Air Sampler (MAS). Data angka kuman dan kualitas lingkungan fisik yang dihasilkan dikategorikan sebagai memenuhi syarat (MS) dan tidak memenuhi syarat (TMS) sedangkan data keberadaan bakteri staphylococcus dinyatakan dalam positif negatif. Untuk melihat pengaruh dari masing variabel indenpendet terhadap dependentnya dianalisis dengan uji chi-square dan regresi logistik.

\section{HASIL}

Hasil identifikasi pada 30 titik/ruangan perawatan Rumah Sakit Islam Faisal Makassar ditemukan bakteri staphylococcus pada semua ruangan yang berbeda jenis yaitu Staphylococcus sp. dan Staphylococcus aureus.

\section{Analisis Uvariat}

Tabel 1.

Distribusi Angka Kuman Udara di Ruang Rawat Inap Rumah Sakit Islam Faisal Makassar

\begin{tabular}{ccc}
\hline $\begin{array}{c}\text { Angka Kuman } \\
\text { Udara }\end{array}$ & n & $\begin{array}{c}\text { Persentase } \\
\text { (\%) }\end{array}$ \\
\hline MS & 12 & 40 \\
TMS & 18 & 80 \\
\hline Total & $\mathbf{3 0}$ & $\mathbf{1 0 0}$ \\
\hline
\end{tabular}

Sumber: Data Primer, 2017

Berdasarkan tabel 1. dapat dilihat hasil pengukuran angka kuman udara yang dilakukan di ruang rawat inap Rumah Sakit Islam Faisal Makasar lebih banyak yang tidak memenuhi syarat dibanding yang memenuhi syarat, dimana dari 30 titik pengukuran terdapat 12 titik yang angka kuman udaranya memenuhi syarat dan 18 titik yang angka kuman udaranya tidak memenuhi syarat.

Tabel 2.

Distribusi Suhu di Ruang Rawat Inap Rumah Sakit Islam Faisal Makassar

\begin{tabular}{ccc}
\hline Suhu & n & Persentase (\%) \\
\hline MS & 7 & 23,3 \\
TMS & 23 & 76,7 \\
\hline Total & $\mathbf{3 0}$ & $\mathbf{1 0 0}$
\end{tabular}

Sumber: Data Primer 2017

Berdasarkan tabel 3 dapat dilihat hasil pengukuran suhu yang dilakukan di ruang rawat inap Rumah Sakit Islam Faisal Makasar lebih banyak yang tidak memenuhi syarat dibanding dengan yang memenuhi syarat, dimana dari 30 titik pengukuran terdapat 7 titik yang suhunya 
http://journal.unpacti.ac.id/index.php/JPP

memenuhi syarat dan 23 titik yang suhunya tidak memenuhi syarat.

Tabel 3.

Distribusi Pencahayaan di Ruang Rawat Inap Rumah Sakit Islam Faisal Makassar

\begin{tabular}{ccc}
\hline Pencahayaan & n & $\begin{array}{c}\text { Persentase } \\
\mathbf{( \% )}\end{array}$ \\
\hline MS & 12 & 40 \\
TMS & 18 & 60 \\
\hline Total & $\mathbf{3 0}$ & $\mathbf{1 0 0}$ \\
\hline
\end{tabular}

Sumber: Data Primer 2017

Berdasarkan tabel 3. dapat dilihat hasil pengukuran pencahayaan yang dilakukan di ruang rawat inap Rumah Sakit Islam Faisal Makasar lebih banyak yang tidak memenuhi syarat dibanding dengan yang memenuhi syarat, dimana dari 30 titik pengukuran terdapat 12 titik yang pencahayaannya memenuhi syarat dan 18 titik yang pencahayaan tidak memenuhi syarat.

Tabel 4.

Distribusi Kelembaban di Ruang Rawat Inap Rumah Sakit Islam Faisal Makassar

\begin{tabular}{lcc}
\hline Kelembaban & n & Persentase (\%) \\
\hline MS & 8 & 26,7 \\
TMS & 22 & 73,3 \\
\hline Jumlah & $\mathbf{3 0}$ & $\mathbf{1 0 0}$
\end{tabular}

Sumber: Data Primer, 2017

Berdasarkan tabel 4. dapat dilihat hasil pengukuran kelembaban yang dilakukan di ruang rawat inap Rumah Sakit Islam Faisal Makasar lebih banyak yang tidak memenuhi syarat dibanding dengan yang memenuhi syarat, dimana dari 30 titik pengukuran terdapat 8 titik yang pencahayaannya memenuhi syarat dan 22 titik yang pencahayaan tidak memenuhi syarat.
Berdasarkan tabel 5. dapat dilihat hasil observasi yang dilakukan di ruang rawat inap Rumah Sakit Islam Faisal Makasar lebih banyak yang tidak memenuhi syarat dibanding dengan yang memenuhi syarat, dimana dari 30 titik pengukuran terdapat 6 titik yang kepadatan huniannya memenuhi syarat dan 24 titik yang kepadatan huniannya tidak memenuhi

Tabel 5.

Distribusi Kepadatan Hunian di Ruang Rawat Inap Rumah Sakit Islam Faisal Makassar

\begin{tabular}{ccc}
\hline Kepadatan Hunian & $\mathbf{n}$ & Persentase (\%) \\
\hline MS & 6 & 20 \\
TMS & 24 & 80 \\
\hline Jumlah & $\mathbf{3 0}$ & $\mathbf{1 0 0}$ \\
\hline Sumber: Data Primer, 2017 &
\end{tabular}

\section{Analisis Bivariat}

Berdasarkan tabel 6. hasil uji statistik antara suhu dengan angka kuman udara diperoleh nilai $p=0,009$. Hal ini menunjukkan terdapat hubungan yang signifikan antara suhu dengan angka kuman udara di ruang rawat inap Rumah Sakit Islam Faisal Makassar. Hasil uji statistik antara pencahayaan dengan angka kuman udara diperoleh nilai $p=0,024$. Hal ini menunjukkan terdapat hubungan yang signifikan antara pencahayaan dengan angka kuman udara di ruang perawatan Rumah Sakit Islam Faisal Makassar. Hasil uji statistik antara kelembaban dengan angka kuman udara diperoleh nilai $p=0,034$. Hal ini menunjukkan terdapat hubungan yang signifikan antara kelembaban dengan angka kuman udara di ruang rawat inap Rumah Sakit Islam Faisal 
http://journal.unpacti.ac.id/index.php/JPP

Makassar. Hasil uji statistik antara kepadatan hunian dengan angka kuman udara diperoleh nilai $p=0,66$. Hal ini menunjukkan tidak terdapat hubungan yang signifikan antara kepadatan hunian dengan angka kuman udara di ruang rawat inap rawat inap Rumah Sakit Islam Faisal Makassar.

\section{Analisis Multivariat}

Berdasarkan tabel 7. hasil uji statistik ketiga variabel yang berhubungan dengan menggunkan regresi logistik dapat dilihat bahwa variabel yang paling berpengaruh terhadap angka kuman udara di ruang rawat inap Rumah Sakit Islam Faisal Makassar.

Tabel 6.

Analisis Hubungan antara Variabel Independen dengan Angka Kuman Udara di ruang rawat inap Rumah Sakit Islam Faisal Makassar

\begin{tabular}{|c|c|c|c|c|c|c|c|}
\hline \multirow{3}{*}{ Variabel } & \multicolumn{4}{|c|}{ Angka Kuman Udara } & \multirow{2}{*}{\multicolumn{2}{|c|}{ Total }} & \multirow{3}{*}{ p-value } \\
\hline & \multicolumn{2}{|c|}{ MS } & \multicolumn{2}{|c|}{ TMS } & & & \\
\hline & $\mathrm{n}$ & $\%$ & $\mathrm{n}$ & $\%$ & $\mathrm{n}$ & $\%$ & \\
\hline \multicolumn{8}{|l|}{ Suhu } \\
\hline MS & 6 & 85,7 & 1 & 14,3 & 7 & 100 & 0,009 \\
\hline TMS & 6 & 26,1 & 17 & 73,9 & 23 & 100 & \\
\hline \multicolumn{8}{|l|}{ Pencahayaan } \\
\hline MS & 8 & 66,7 & 4 & 33,3 & 12 & 100 & 0,024 \\
\hline TMS & 4 & 22,2 & 14 & 77,8 & 18 & 100 & \\
\hline \multicolumn{8}{|l|}{ Kelembaban } \\
\hline MS & 6 & 75,0 & 2 & 25,0 & 8 & 100 & 0,034 \\
\hline TMS & 6 & 27,3 & 16 & 72,7 & 22 & 100 & \\
\hline \multicolumn{8}{|c|}{ Kepadatan Hunian } \\
\hline MS & 3 & 50,0 & 3 & 50,0 & 6 & 100 & 0,66 \\
\hline TMS & 9 & 37,5 & 15 & 62,5 & 24 & 100 & \\
\hline Total & 12 & 40,0 & 18 & 60,0 & 30 & 100 & \\
\hline
\end{tabular}

Sumber: Data Primer, 2017

Tabel 7.

Analisis Pengaruh Suhu, Pencahayaan, Kelembaban dan Kepadatan Hunian Dengan Angka Kuman Udara di ruang rawat inap Rumah Sakit Islam Faisal Makassar

\begin{tabular}{ccccccccc}
\hline Variabel & B & SE & Wald & df & Sig. & Exp (B) & \multicolumn{2}{c}{ 95\% C.I.for EXP(B) } \\
\hline Suhu & $3.3 \overline{1} 6$ & 1.552 & 4.564 & 1 & .033 & .036 & .002 & .761 \\
Pencahayaan & 3.265 & 1.427 & 5.236 & 1 & .022 & .038 & .002 & .626 \\
Kelembaban & $2.6 \overline{6} 5$ & 1.405 & 3.596 & 1 & .058 & .070 & .004 & 1.094 \\
\hline Constant & 3.649 & 1.387 & 6.924 & 1 & .009 & 38.448 & & \\
\hline
\end{tabular}

Sumber: Data Primer, 2017 


\section{PEMBAHASAN}

\section{Hubungan Suhu dengan Angka Kuman Udara}

Dari hasil pengukuran suhu di ruang rawat ini Rumah Sakit Islam Faisal Makassar diperoleh rerata $26^{\circ} \mathrm{C}$, suhu tersebut melebihi standar yang telah ditetapkan, sebagian besar suhu di dalam ruang perawatan tidak memenuhi syarat, dimana hanya $\quad 23,3 \%$ ruangan yang memenuhi syarat dan $76,7 \%$ yang tidak memenuhi syarat.

Dari hasil uji statistik untuk melihat hubungan antara suhu terhadap angka kuman udara diperoleh nilai $p=0,009<0,05$ yang berarti ada hubungan yang bermakna antara suhu terhadap angka kuman udara. Penelitian ini sejalan dengan penelitian yang dilakukan oleh Didik Agus Nugroho (2016) di rawat inap kelas III RSUD Dr. Moewardi Surakarta berdasarkan hasil uji statistik menunjukan ada hubungan antara suhu dengan angka kuman udara. Hal ini dimungkinkan karena suhu adalah faktor yang terpenting yang mempengaruhi pertumbuhan, multiplikasi dan kelangsungan dari semua organisme hidup. Suhu yang rendah umumnya memperlambat metabolisme seluler sedangkan suhu yang lebih tinggi meningkatkan taraf kegiatan sel. (Koes Irianto, 2013).

\section{Hubungan Pencahayaan dengan Angka Kuman Udara.}

Dari hasil pengukuran pencahayaan di dalam ruang rawat inap Rumah Sakit Islam Faisal Makassar diperoleh nilai rerata 115,4 lux nilai tersebut memenuhi standar yang ditetapkan. Ruang perawatan yang pencahayaannya memenuhi syarat $40 \%$ dan tidak memenuhi syarat $60 \%$.

Dari hasil uji statistik diperoleh nilai $p=$ $0,017<0,05$ yang berarti ada hubungan yang bermakna antara pencahayaan terhadap angka kuman udara. Hasil penelitian ini sejalan dengan penelitian yang dilakukan oleh Tina Apnah Ningsih (2016) di ruang rawat inap RSUD DR. M. Haulussy ambon provinsi Maluku berdasarkan hasil uji hubungan antara pencahayaan dengan angka kuman udara menunjukkan bahwa pencahayaan memiliki hubungan yang bermakna dengan angka kuman udara.

\section{Hubungan Kelembaban dengan Angka Kuman Udara.}

Hasil pengukuran kelembaban di ruang perawatan diperoleh rerata $70,9 \% \mathrm{RH}$, sebagian besar kelembaban udara di dalam ruang perawatan tidak memenuhi syarat dimana hanya $26,7 \%$ ruangan yang memenuhi syarat dan 73,3\% yang tidak memenuhi syarat. Dari hasil uji statistik diperoleh nilai $p=0,034<$ 0,05 yang berarti ada hubungan yang bermakna antara kelembaban terhadap angka kuman udara. Hasil penelitian ini sejalan dengan penelitian yang dilakukan oleh Rizal Muntaha, dkk (2016) di ruang rawat inap gedung Sitti Hajar Rumah Sakit Islam Sultan Hadlirin Jepara berdasarkan hasil uji hubungan kelembaban dengan angka kuman udara menunjukkan bahwa kelembaban 
berhubungan langsung dengan angka kuman udara.

\section{Hubungan Kepadatan Hunian dengan Angka Kuman Udara.}

Hasil observasi kepadatan hunian di ruang perawatan diperoleh rerata 6,8 nilai tersebut tidak memenuhi standar yang ditetapkan menurut standar. Sebagian besar kepadatan hunian di dalam ruang perawatan tidak memenuhi syarat, dimana hanya $20 \%$ ruangan yang memenuhi syarat dan $80 \%$ yang tidak memenuhi syarat.

Hasil uji statistik diperoleh nilai $p=$ $0,660>0,05$ yang berarti tidak ada hubungan yang bermakna antara kepadatan hunian dengan angka kuman udara. Hasil penelitian ini sejalan dengan penelitian yang dilakukan oleh Tahir Abdullah (2011) berdasarkan hasil uji hubungan kepadatan hunian dengan jumlah bakteri menunjukkan bahwa kepadatan hunian tidak berhubungan dengan jumlah angka kuman udara.

\section{KESIMPULAN}

1. Berdasarkan hasil dentifikasi ditemukan 2 jenis bakteri stahpylococcus pada ruang perawatan yaitu bakteri staphylococcus $s p$. dan staphylococcus aureus.

2. Berdasarkan Peraturan Menteri Kesehatan Republik Indonesia No. 1204 tahun 2004 tentang persyaratan Lingkungan Rumah Sakit dan Peraturan Menteri Kesehatan No. 829 Tahun 1999 tentang Persyaratan
Kesehatan Perumahan untuk kamar hunian sebagian besar tidak memenuhi syarat.

3. Dari hasil analisis bivariat empat faktor lingkungan fisik lingkungan terhadap angka kuman udara menunjukkan ada hubungan yang bermakna antara suhu, pencahayaan dan kelembaban terhadap angka kuman udara, sedangkan kepadatan hunian tidak berhubungan langsung dengan angka kuman udara.

4. Dari hasil analisis multivariat variabel suhu dan pencahayaan yang paling berpengaruh terhadap angka kuman udara.

\section{SARAN}

1. Sebaiknya pengelola Rumah Sakit Islam Faisal Makassar memodifikasi ruang perawatan sehingga faktor lingkungan fisik memenuhi persyaratan kualitas lingkungan fisik rumah sakit.

2. Bagi peneliti selanjutnya diharapkan dapat meneliti seluruh faktor lingkungan fisik yang berhubungan dengan angka kuman udara di ruang rawat inap rumah sakit maupun di ruangan lain.

\section{DAFTAR PUSTAKA}

Achmadi, U.F., 2008. Manajemen Penyakit Berbasis Wilayah. Jakarta. PT Raja Grafindo Persada.

AN, Tinah. 2016. Faktor Yang Berhubungan Dengan Angka Kuman di Ruang Rawat Inap RSUD DR. M. Haulussy Ambon provinsi Maluku. Yogyakarta. Fakultas 
http://journal.unpacti.ac.id/index.php/JPP

Kesehatan Masyarakat. Universitas Gadjah Mada.

Abdullah, Tahir. 2011. Lingkungan Fisik dan Angka Kuman Udara Ruangan di Rumah Sakit Umum Haji Makassar, Sulawesi Selatan.

Dewi E. dkk, 2016. Tingginya Prevalensi MRSA pada Isolat Klinik Periode 2010- 2014 di RSUD Dr. Saiful Anwar Malang, Indonesia. Jurnal Kedokteran Brawijaya Vol 29, No. 2. Online: http://jkb.ub.ac.id/index.php/jkb/article/vi ew/1200. (diakses 8 Agustus 2016)

Depkes. RI. 1999. Kepmenkes RI No.829/Menkes/SK/VII/1999, Tentang Persyaratan Kesehatan Perumahan.

Depkes RI. Jakarta. 2004. Depkes RI. No 1204/MENKES/SK/X/2004 tentang Persyaratan Kesehatan Lingkungan Rumah Sakit. Jakarta.
Haryono. 2013. Infeksi Nosokomial Rumah Sakit. Jakarta: Renika.

Muntaha, Rizal dkk. 2016. Faktor Lingkungan Fisik Ruangan dengan Angka Kuman Udara Ruang Rawat Inap Gedung Sitti Hajar Rumah Sakit Islam Sultan Hadlirin Jepara. Vol. 1, No. 5- Oktober. On-line http://jurnal.stikescendekiautamakudus.ac .id/

Nugroho, Didik Agus. 2016. Faktor-Faktor yang Berhubungan dengan Angka Kuman Udara di Rawat Inap Kelas III RSUD Dr.moewardi surakarta. Semarang. Fakultas Kesehatan Masyarakat universitas Diponegoro.

Wikansari. 2012. Pemeriksaan Total Kuman Udara dan Staphylococus Aureus di Ruang Rawat Inap Rumah Sakit X Kota Semarang Tahun 2012. 